\author{
V. Hud ${ }^{1}$, I. Hevko ${ }^{1}$, O. Lyashuk ${ }^{1}$, O. Hevko ${ }^{1}$, M. Sokol ${ }^{2}$, I. Shust ${ }^{1}$ \\ ${ }^{I}$ Ternopil Ivan Puluj National Technical University, Ukraine; \\ ${ }^{2}$ I.Ya. Gorbachevskyy Ternopil National Medical University, Ukraine \\ (E-mail:vic_g@ukr.net)
}

\title{
Research of resonance vibrations of the system «Telescopic screw — bulk medium» caused by torsional vibrations
}

\begin{abstract}
The article outlines the relevance of using the principle of telescopy in the process of creation screw conveyors, which nowadays are folded to obtain significant lengths, which makes their designs expensive and structurally unreasonably complicated. It has been shown an experimental equipment, which provides measurement results of the research process in a wide range with high accuracy in an automated control mode with the necessary data capture. Based on the constructed mathematical model, the dependences of the angular perturbation velocity on the physicomechanical and geometric parameters of the «telescopic screw — bulk medium» system have been obtained. Because of analytical relations describing the laws of variation of characteristic parameters for its oscillation resonance case have been received. It has been proved that for resonant oscillations, when there are significant angular velocities of rotation, the natural frequency of the bending oscillations is smaller and at the same time the amplitude of the transition through the resonance is smaller. The results of the amplitude of the transverse oscillations of the system for different values of the angular velocity of rotation in time during the transition through the internal resonance, which largely depends on the physicomechanical and geometric characteristics of the motion of the medium, have been presented.
\end{abstract}

Keywords: conveyors, mechanical systems, transporting-separating system, dynamic modeling, amplitude, resonance, telescopic screw, bulk medium, angular velocity of rotation, torsional vibrations.

\section{Introduction}

Screw conveyors are widely used in various sectors of the economy as independent mechanisms, and as part of various mechanical systems. They are often used as elements of agricultural machinery when harvesting for transshipment of various cargoes in the field. Screw conveyors as part of universal units for loading seeders, hoppers, reloaders and combine harvesters are usually complex and involve decomposition-folding using hydraulic or pneumatic equipment, which makes their designs too complicated and expensive.

Mainly for transportation of such cargoes rigid auger conveyors installed at different angles to the horizon are used, as well as flexible screw conveyors, the determination of the parameters and modes of which are described in the works [1-4].

In article [5-9] dependence in time of the amplitude and frequency of nonlinear vibrations of the feeder horizontal working body at its various geometric dimensions, the angular velocity of the working body rotation, the grain mixture mass per unit length, and the speed of its transportation

The works of [10-15] provide research findings on flow patterns of bulk materials depending on constructional and kinematic characteristics of screw operating tools, bunker type and solid particles, as well as frictional forces. Findings of mentioned researches shows on improved characteristics of screw conveyors during transportation of bulk materials.

Despite the large number of scientific works devoted to the development and study of the peculiarities of the work of screw conveyors, there is a wide range of unexplored issues related to their structural and functional characteristics. Therefore, telescopic screw conveyors have been developed to improve the structures and provide the necessary trajectory of material loading with screw conveyors. These telescopic screw conveyors will improve productivity on tracks with variable length and direction of overload, as well as performing related technological operations with transported raw materials [16]. According to the experimental and separate theoretical studies of the dynamics of the working bodies of screw conveyors [17-18], the movement of the manufacturing medium along the previous one affects the quantitative, and in some cases, the qualitative characteristics of their oscillations. However, due to the large angular rotational speeds of the screw in telescopic screw conveyors, asymmetry of the telescopic screw and external perturbations often cause oscillations in significant dynamic loads on the screw, especially in resonant cases. The study of dy- 
namic loads arising in the auger of the telescopic conveyor will allow you to find the optimal mode of operation. These modes minimize dynamic loads and increase the service life of these conveyors.

\section{Material and method}

In order to study the characteristics of telescopic screw conveyors and based on our patent search and analysis of scientific literature, we synthesized telescopic screw conveyors [19-21] based on which a stand was designed and manufactured to study the transportation of bulk cargo (Fig. 1) [22]. To perform a research the following actions has been done in such order: load the hopper 14 with loose material, which from it enters the casing 3 on the auger 2, by which it is transported to the casing 6 to the auger 5 , and then the bulk material through the discharge pipe 9 falls into the measuring vessel. The rotary movement of the auger 2 obtains through the belt drive 16 from the electrodrive 15, which is controlled from the PC 18 with the fixation of all the necessary data in a tabular or graphical form according to the developed methodology of experimental research. From the auger 2 rotary motion is transferred to the auger 5 due to the friction that occurs between the walls of the augers, which allows to carry out the process of overloading the bulk material. In this case, the performance of the telescopic screw conveyor at different casing fill rates and screw speeds is determined in a semi-automatic mode. The power characteristics can be determined by smooth and sudden start-up, reversal and simulation of various loads in an automated mode using a frequency converter and a personal computer.

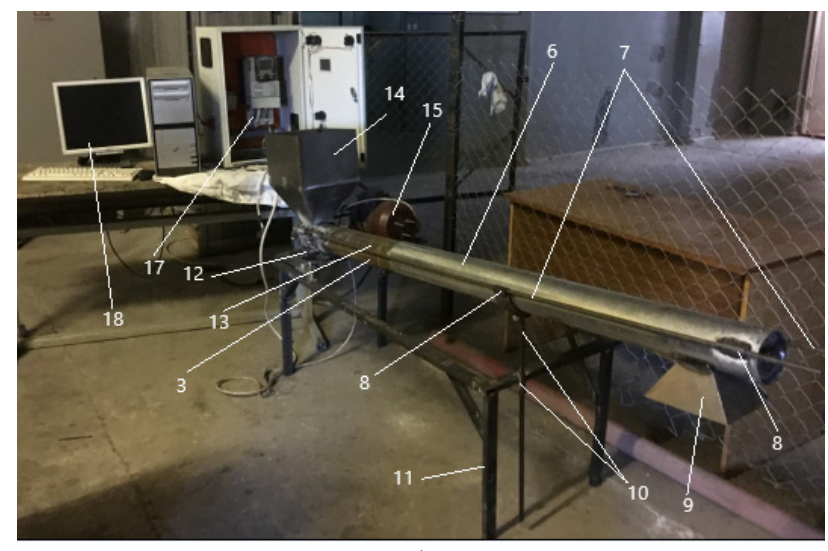

a)

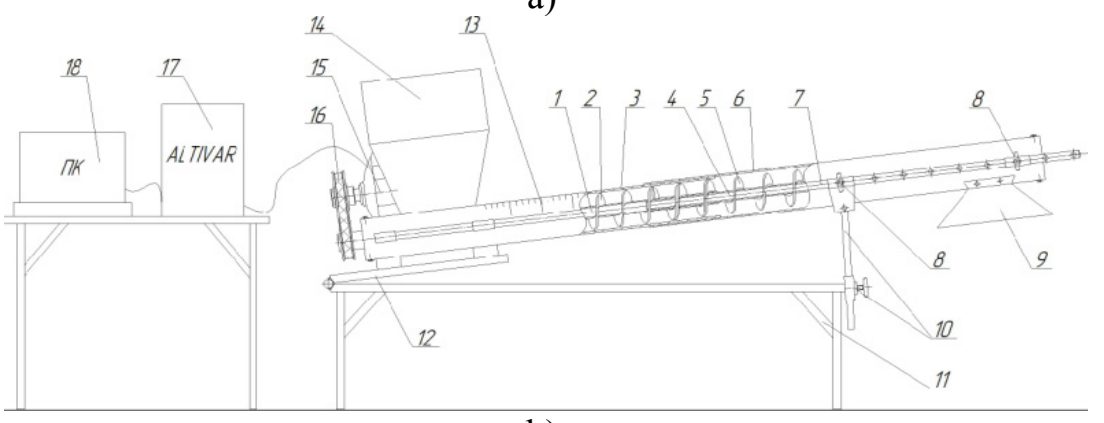

b)

Figure 1. Stand for the study of the characteristics of telescopic screw conveyors: a) General view; b) design diagram; 1) fixed axial section of the screw; 2) auger fixed in the axial direction of the screw section; 3) the axially fixed part of the casing; 4) axially movable screw section; 5) auger movable in the axial direction of the screw section; 6) axially movable part of the casing; 7) guides; 8) fixation of guides; 9) unloading pipe; 10) support for adjusting the feed height of the material; 11) frame; 12) movable table; 13) scale of overlap of augers; 14) a hopper; 15) electric drive of the conveyor; 16) belt transfer; 17) drive frequency converter; 18) personal computer

Exploring the characteristics of telescopic screw conveyors established [19], the resonant vibrations of the system «Telescopic screw is a bulk medium» due to torsional vibrations. The most interesting and at the same time least studied case of complex vibrations in the screw of the telescopic conveyor is the case of internal resonance. Despite the limited amplitude of torsional vibrations in cases where the natural bending and indicated frequencies are close or connected by a rational ratio, the dynamic process of the «telescopic screw is a bulk medium» system is characterized by an increase in the amplitude of bend- 
ing vibrations. To study them, first of all, we consider the terms of the dependences, taking into account the torsional vibrations of the telescopic screw.

These expressions are the following:

$$
2\left(\rho_{1}+\rho_{2}\right) \frac{\partial \vartheta(z, t)}{\partial t} \frac{\partial w}{\partial t}+2\left(\rho_{1}+\rho_{2}\right) I \frac{\partial \vartheta(z, t)}{\partial t} \frac{\partial^{3} w}{\partial t \partial x^{2}}+2\left(\rho_{1}+\rho_{2}\right) \Omega \frac{\partial \vartheta(z, t)}{\partial t} u+\left(\rho_{1}+\rho_{2}\right) \frac{\partial^{2} \vartheta(z, t)}{\partial t^{2}} w
$$

Or

$$
-2\left(\rho_{1}+\rho_{2}\right) \frac{\partial \vartheta(z, t)}{\partial t} \frac{\partial u}{\partial t}-2\left(\rho_{1}+\rho_{2}\right) I \frac{\partial \vartheta(z, t)}{\partial t} \frac{\partial^{3} u}{\partial t \partial x^{2}}-2\left(\rho_{1}+\rho_{2}\right) \Omega \frac{\partial \vartheta(z, t)}{\partial t} w\left(\rho_{1}+\rho_{2}\right) \frac{\partial^{2} \vartheta(z, t)}{\partial t^{2}} u
$$

Taking into account the law of rotational oscillations of a telescopic screw in the form

$$
\vartheta(x, t)=h \sin \frac{k \pi}{l(\tau)} z \cos \vartheta, \vartheta=\left(\Theta t+\vartheta_{0}\right),
$$

where $a$ - is their amplitude, $\Theta=\frac{k \pi}{l(\tau)} \sqrt{\frac{G J_{0}}{I_{0}}}$ - frequency, $\vartheta_{0}$ - initial phase, $I_{0}$ the running moment of inertia relative to the neutral axis of the elastic body together with the medium, $J_{0}$ - is its equatorial moment of inertia, $\mathrm{G}-$ is the shear modulus.

Then the expressions of the right-hand side of the differential relations that take them into account are transformed to the form:

$$
2 a_{s} h \sin \frac{k \pi}{l} z \sin \frac{s \pi}{l} z\left\{\left(1-I\left(\frac{s \pi}{l}\right)^{2}+\frac{\Theta_{k}}{\omega_{s}}\right) \sin \psi_{s} \sin \left(\Theta_{k} t+\vartheta_{0}\right)-\frac{\Theta_{k}}{\omega_{s}} \cos \psi_{s} \cos \left(\Theta_{k} t+\vartheta_{0}\right)\right\} .
$$

Let us consider them in more detail for the case where the forms of transverse and torsional oscillations are close in frequency i.e. $\omega_{s}=\Theta_{k}$. In that case, the additives of the right side of the general relations

$$
\begin{aligned}
& \frac{\partial u(t, z)}{\partial t}=-a \omega(\sin (\kappa z+\omega t+\phi)+\sin (\kappa z-\omega t-\phi), \\
& \frac{\partial w(t, z)}{\partial t}=a \omega(\cos (\kappa z+\omega t+\phi)-\cos (\kappa z-\omega t-\phi)) .
\end{aligned}
$$

The effect on the dynamics of the system of torsional oscillations and the motion determines at of the medium expressions $\cos ^{2} \psi_{s}$ and $\sin ^{2} \psi_{s}$ replace accordingly for $\frac{1}{2}\left(1+\cos 2 \psi_{s}\right)$ and $\frac{1}{2}\left(1-\cos 2 \psi_{s}\right)$, system of differential equations

$$
\begin{gathered}
\frac{d a}{d t}=-\frac{1}{2 \pi \omega l\left(\rho_{1}+\rho_{2}\right)} \int_{0}^{l} \int_{0}^{2 \pi} \tilde{f}(a, z, \psi, \gamma, \vartheta)(\cos (\kappa z+\psi)-\cos (\kappa z-\psi)) d \psi d z, \\
\frac{d \theta}{d t}=\omega+\frac{1}{2 a \pi \omega l\left(\rho_{1}+\rho_{2}\right)} \int_{0}^{l} \int_{0}^{2 \pi} \tilde{f}(a, z, \psi, \gamma, \vartheta)(\sin (\kappa z+\psi)+\sin (\kappa z-\psi)) d \psi d z, .
\end{gathered}
$$

After averaging over the linear variable and the external perturbation phase, it transforms to the form:

$$
\begin{gathered}
\frac{d a}{d t}=-\frac{\varepsilon}{4 \pi \omega_{i} l} \int_{0}^{l} \int_{0}^{2 \pi} \tilde{f}\left(a, z, \psi_{S}, \gamma\right)(\cos (\kappa z+\phi+\gamma)-\cos (\kappa z-\phi+\gamma)) d \gamma d \vartheta d z+ \\
+2 a_{S} \omega_{S} \Theta_{k} h \delta_{k}^{S}\left\{\left(1-I\left(\frac{s \pi}{l}\right)^{2}+\frac{\Theta_{k}}{\omega_{S}}\right) \sin 2\left(\omega_{S}+\bar{\gamma}\right) \sin \left(\Theta_{k} t+\vartheta_{0}\right)-\frac{\Theta_{k}}{\omega_{S}}\left(1+\cos 2\left(\omega_{S}+\varphi\right) \cos \left(\Theta_{k} t+\vartheta_{0}\right)\right)\right\} \\
\frac{d \psi_{S}}{d t}=\omega_{S}+\frac{\varepsilon}{4 a \pi \omega_{S} l} \int_{0}^{2 \pi} \int_{0}^{l} \int_{0}^{2 \pi} \tilde{f}\left(a, z, \psi_{S}, \gamma\right)(\sin (\kappa z+\phi+\gamma)+\sin (\kappa z-\phi+\gamma)) d \gamma d \vartheta d z-
\end{gathered}
$$




$$
\left.-a_{S} \omega_{S} \Theta_{k} h \delta_{k}^{S}\left\{\left(1-I\left(\frac{s \pi}{l}\right)^{2}+\frac{\Theta_{k}}{\omega_{S}}\right) \cos 2\left(\omega t_{S}+\bar{\gamma}\right) \sin \left(\Theta_{k} t+\vartheta_{0}\right)-\frac{\Theta_{k}}{2 \omega_{S}} \sin 2\left(\omega t_{S}+\bar{\gamma}\right) \cos \left(\Theta_{k} t+\vartheta_{0}\right)\right)\right\}
$$

where $\delta_{s}^{k}=\frac{1}{l} \int_{0}^{l} \sin \frac{k \pi}{l} z \sin ^{2} \kappa_{s} z d z$

Relations (1) show that, if the condition is fulfilled $2 \omega_{s} \approx \omega_{\text {sk }}$, there will be resonant transverse oscillations in the system, which are caused by torsional oscillations. To describe them, in the same way as for resonant oscillations at the frequency of external periodic perturbation, entering in equation (1) the phase difference $\phi_{2}=2 \psi_{s}-\vartheta_{k}\left(\phi_{2}+\vartheta_{k}=2 \psi_{s}\right)$, we get:

$$
\begin{gathered}
\frac{d a}{d t}=\frac{-\bar{\varepsilon}}{4 \omega_{s} \pi l} \int_{0}^{l} \int_{0}^{2 \pi} \tilde{f}\left(b_{1}, z, \psi_{s}, \gamma\right) \sin \kappa_{s} z \cos \psi_{s} d z d \gamma+a b_{s} \omega_{s} \omega_{\vartheta k} \delta_{s}^{k}\left(1-I \kappa_{s}^{2}+\frac{\Omega}{\omega_{1}}-\omega_{\vartheta 1}\right) \tilde{n} o s \phi_{2}, \\
\frac{d \phi_{2}}{d t}=2 \omega_{s}-\omega_{\vartheta л}+\frac{-\bar{\varepsilon}}{4 \omega_{s} b_{s} \pi l} \int_{0}^{l} \int_{0}^{2 \pi} \tilde{f}\left(b_{1}, z, \psi_{s}, \gamma\right) \sin \kappa_{s} z \sin \psi_{s} d z d \gamma+a \omega_{s} \omega_{\vartheta k} \delta_{1}^{k}\left(1-I \kappa_{1}^{2}+\frac{\Omega}{\omega_{1}}-\omega_{\vartheta k}\right) \sin \phi_{2}
\end{gathered}
$$

If the function $f_{1}\left(u, w, \frac{\partial u}{\partial t}, \ldots, \frac{\partial^{3} w}{\partial z^{3}}, \gamma\right)$ takes into account only the forces of resistance and external periodic perturbation, that is, expressed by the ratio

$$
\begin{gathered}
-\frac{d a}{d t} \omega(\sin (\kappa z+\omega t+\varphi)+\sin (\kappa z-\omega t-\varphi))+a \omega \frac{d \varphi}{d t}(\cos (\kappa z+\omega t+\varphi)- \\
-\cos (\kappa z-\omega t-\varphi))=\varepsilon \tilde{f}(a, x, \psi, \vartheta), \\
-a \frac{d \varphi}{d t}(\sin (\kappa z+\omega t+\varphi)+\sin (\kappa z-\omega t-\varphi))+\frac{d a}{d t}(\cos (\kappa z+\omega t+\varphi)-\cos (\kappa z-\omega t-\varphi))=0, \\
\frac{d a}{d t} \omega(\cos (\kappa z+\omega t+\varphi)-\cos (\kappa z-\omega t-\varphi))-a \omega \frac{d \varphi}{d t}(\sin (\kappa z+\omega t+\varphi)+ \\
+\sin (\kappa z-\omega t-\phi))=\varepsilon \tilde{g}(a, z, \psi, \gamma, \vartheta), \text { where } \varepsilon \tilde{f}(a, x, \psi, \gamma, \vartheta), \varepsilon \tilde{g}(a, z, \psi, \gamma, \vartheta) \\
\text { Then the } \operatorname{correspond} \text { to the values respectively of the function } \\
f_{1}\left(u, w, \frac{\partial u}{\partial t}, \ldots, \frac{\partial^{3} w}{\partial z^{3}}, \gamma\right)+2\left(\rho_{1}+\rho_{2}\right) \frac{\partial \vartheta(z, t)}{\partial t} \frac{\partial w}{\partial t}+2\left(\rho_{1}+\rho_{2}\right) I \frac{\partial \vartheta(z, t)}{\partial t} \frac{\partial^{3} w}{\partial t \partial x^{2}}+2\left(\rho_{1}+\rho_{2}\right) \Omega \frac{\partial \vartheta(z, t)}{\partial t} u+\left(\rho_{1}+\rho_{2}\right) \frac{\partial^{2} \vartheta(z, t)}{\partial t^{2}} w, \\
f_{2}\left(u, w, \frac{\partial u}{\partial t}, \ldots, \frac{\partial^{3} w}{\partial z^{3}}, \gamma\right)-2\left(\rho_{1}+\rho_{2}\right) \frac{\partial \vartheta(z, t)}{\partial t} \frac{\partial u}{\partial t}-2\left(\rho_{1}+\rho_{2}\right) I \frac{\partial \vartheta(z, t)}{\partial t} \frac{\partial^{3} u}{\partial t \partial x^{2}}-2\left(\rho_{1}+\rho_{2}\right) \Omega \frac{\partial \vartheta(z, t)}{\partial t} w\left(\rho_{1}+\rho_{2}\right) \frac{\partial^{2} \vartheta(z, t)}{\partial t^{2}} u .
\end{gathered}
$$

Then the transverse resonance oscillations caused by the torsional oscillations in the case are described by differential equations:

$$
\begin{aligned}
& \frac{d a}{d t}=\frac{k_{1}(\omega)^{s-1}}{\left(\rho_{1}+\rho_{2}\right) \pi} a^{s}+\frac{4}{3} a b_{1} \omega_{\vartheta 1}\left(1-I \kappa_{1}^{2}+\frac{\Omega}{\omega_{1}}-\frac{\omega_{\vartheta 1}}{\omega_{1}}\right) \cos \phi_{2}, \\
& \frac{d \phi_{2}}{d t}=2 \omega_{1}-\omega_{\vartheta 1}-\frac{\overline{k_{1}} E I}{\left(\rho_{1}+\rho_{2}\right)} a^{2}-\left(\frac{\pi}{l}\right)^{2} \frac{\rho_{2}}{8 \omega\left(\rho_{1}+\rho_{2}\right)} V^{2}+\frac{4}{3} a \omega_{\vartheta 1}\left(1-I \kappa_{1}^{2}+\frac{\Omega}{\omega_{1}}-\frac{\omega_{\vartheta 1}}{\omega_{1}}\right) \sin \phi_{2}
\end{aligned}
$$

In Figure 2 presents for different values of the angular velocity of rotation the change in the amplitude time of the transverse oscillations of the system during the transition of the internal resonance. 


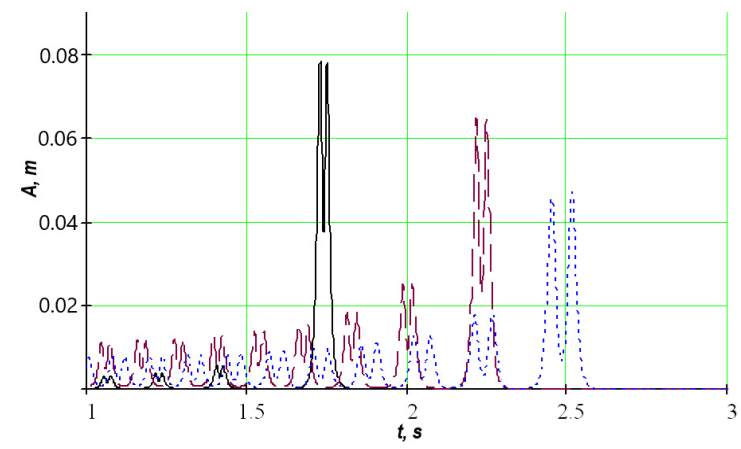

a)
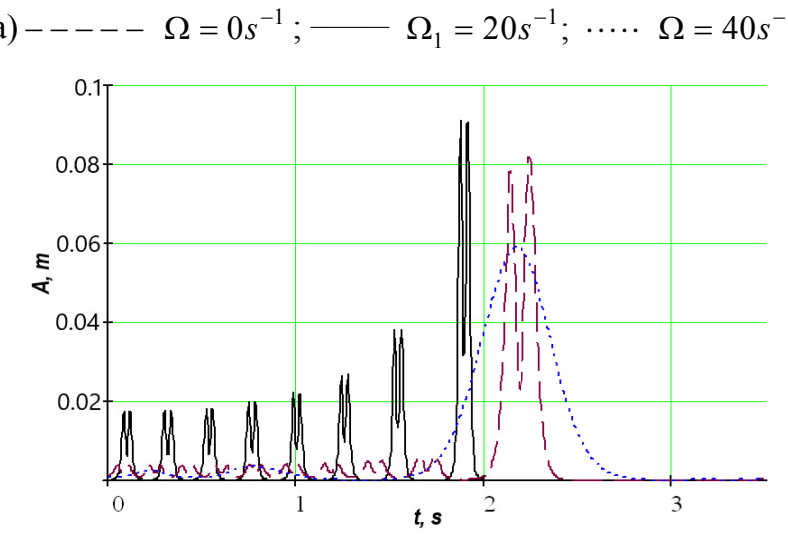

c)
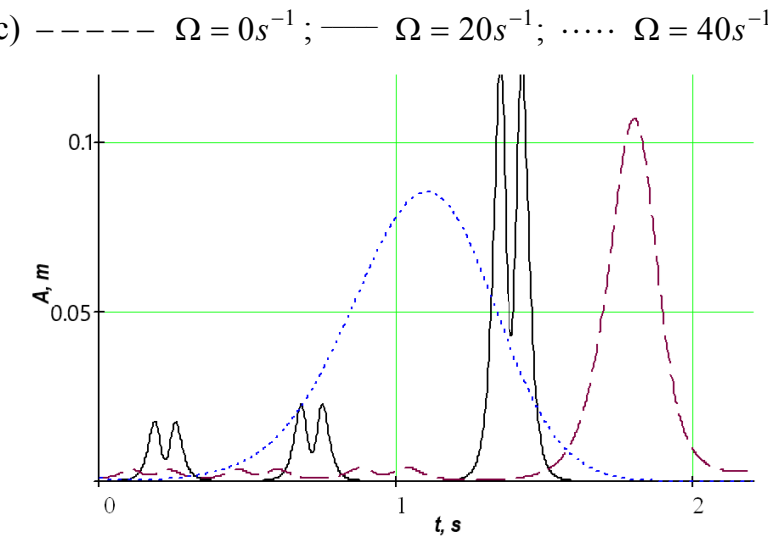

e) ----- $\Omega=0 s^{-1} ; \quad \Omega=10 s^{-1} ; \quad \ldots . \Omega \Omega=25 s^{-1}$

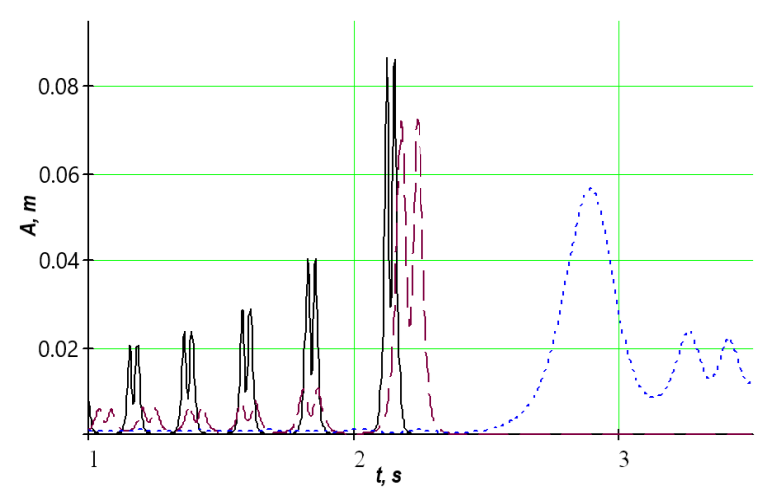

b) $-----\Omega=0 s^{-1} ;-\Omega_{1}=20 s^{-1} ; \cdots \Omega \Omega=40 s^{-1}$

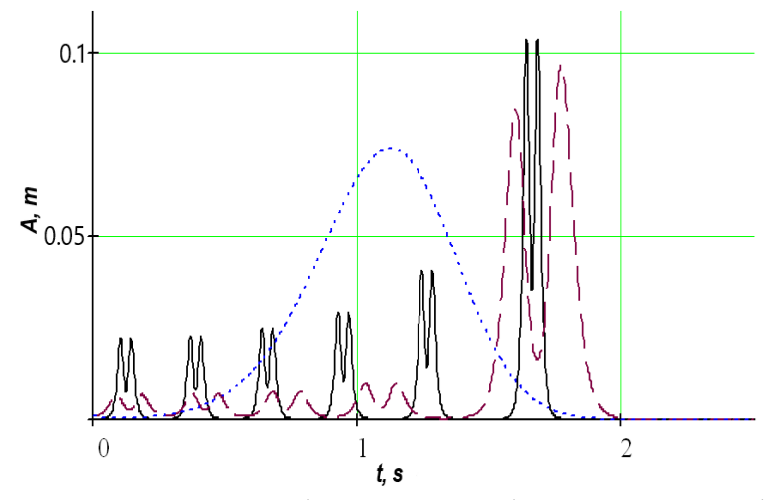

d)

$\Omega=0 s^{-1}$

$\Omega=20 \mathrm{~s}^{-1}$;

$\Omega=40 s^{-1}$

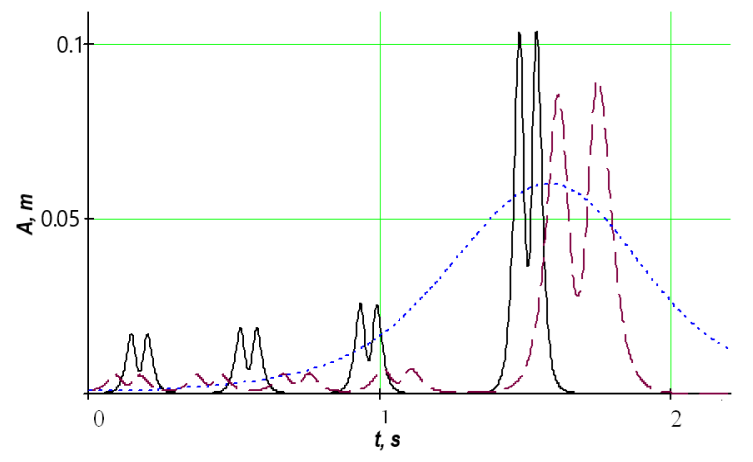

$\Omega=0 s^{-1} ; \quad \Omega=10 s^{-1} ;$

$\Omega=25 s^{-1}$

Figure 2. Changing the amplitude of the bending vibrations of the screw during the transition through internal resonance at $\rho_{1}=10 \mathrm{~kg} / \mathrm{m} ; I=6 \cdot 10^{-6} \mathrm{~kg} / \mathrm{m}^{2} ; E=2,06 \cdot 10^{11} \mathrm{H} / \mathrm{m}^{2} ; V=10 \mathrm{~m} / \mathrm{s}:$ a) $\left.\rho_{2}=0 \mathrm{~kg} / \mathrm{m} ; l=6 \mathrm{~m} ; \mathrm{b}\right) \rho_{2}=10 \mathrm{~kg} / \mathrm{m}$; $l=6 \mathrm{~m}$; c) $\rho_{2}=20 \mathrm{~kg} / \mathrm{m} ; l=6 \mathrm{~m}$; d) $\rho_{2}=30 \mathrm{~kg} / \mathrm{m} ; l=6 \mathrm{~m}$; e) $\rho_{2}=30 \mathrm{~kg} / \mathrm{m} ; l=8 \mathrm{~m} ;$ f) $\rho_{2}=15 \mathrm{~kg} / \mathrm{m} ; l=8 \mathrm{~m}$

\section{Discussion}

The results show that both external and internal resonance can be avoided by changing the angular velocity of the auger, and as for the process of transition through the internal resonance, then:

- for higher angular velocities of rotation, the natural frequency of bending oscillations is smaller and simultaneously the amplitude of the transition is smaller;

- for larger values of the relative amount of motion of the medium, the amplitude of the transition through the internal resonance takes on a larger value.

\section{Conclusions}

Theoretical calculations of the resonance phenomenon have shown that external periodic forces or torsional vibrations of the telescopic screw itself have caused them. Differential equations of transverse oscillations of a rotating elastic body have been deduced under the motion condition of a continuous stream 
of homogeneous medium on it with a constant relative linear velocity $V=10 \mathrm{~m} / \mathrm{s}$. Based on the constructed mathematical model, dependences have been obtained to determine the change in the amplitude of the transverse oscillations of the system during the transition of the internal resonance for different values of the angular velocity of rotation, depending on the physical-mechanical and geometric parameters of the system «telescopic screw-grain mixture» and the angular velocity of the screw rotary organ. It is established that for larger values of angular velocity of rotation of the working body the resonant frequency value is smaller (at $L=6 \mathrm{~m}=20-40 \mathrm{~s}^{-1}$ ). For working bodies of greater length, the amplitude of the transition through the resonance is greater (from 10-25 s-1 at $L=8 \mathrm{~m}$ ) and increases from 0.0393 to $0.1023 \mathrm{~m}$. However, it has established that the external and internal resonances of the system «telescopic screw - loose medium» can be avoided by changing the angular velocity of the working screw.

\section{References}

1 Hevko R.B. Determination of interaction parameters and grain material flow motion on screw conveyor elastic section surface / S.Z. Zalutskyi, Y.B. Hladyo, I.G. Tkachenko, O.L. Lyashuk, O.M. Pavlova, B.V. Pohrishchuk, O.M. Trokhaniak, N.V. Dobizha // INMATEH — Agricultural Engineering. - 2019. — 57 (1). — P. 123-134.

2 Haydl H.M. Design aspects of large-diameter tubular conveyor galleries / H.M. Haydl // Proceedings of the institution of civil engineers. Part 1 - Design and construction. - 1986. - 80. - P. 633-639.

3 Owen Philip J. Screw conveyor performance: comparison of discrete element modelling with laboratory experiments / Philip J. Owen, Paul W. Cleary // Progress in computational fluid dynamics. — 2010. - 10 (5-6). - P. 327-333.

4 Roberts Alan W. Bulk Solids. Optimizing Screw Conveyors / Alan W. Roberts // Chemical engineering. — 2015. — 122(2). - P. 62-67.

5 Lyashuk O.L. Mathematical model of bending vibrations of a horizontal feeder-mixer along the flow of grain mixture / O.L. Lyashuk, M.B. Sokil, V.M. Klendiy, O.P. Skyba, L.M. Slobodian // INMATEH — Agricultural Engineering. - 2018. — 55(2). - P. 33-42.

6 Lutsiv I.V. Investigation of dynamical impact loads in screw conveyer drives with safety clutches/ I.V. Lutsiv, I.B. Hevko, O.L. Lyashuk, T.S. Dubynyak // INMATEH - Agricultural Engineering. - 2017. - 51(1). — P. 69-77.

7 Hevko R.B. Development of a pneumatic screw conveyor design and substantiation of its parameters / R.B. Hevko, O.M. Strishenets, O.L. Lyashuk, I.G. Tkachenko, O.M. Klendii, V.O. Dzyura // INMATEH: Agricultural engineering. — 2018 . - 54(1). - P. 153-160.

8 Hevko I. Resonant oscillation of vertical working part of conveyer-loader / I. Hevko, O. Lyashuk, M. Sokil, L. Slobodian, V. Hud, Yu. Vovk // Bulletin of the Karaganda University. Series PHYSICS. — 2019. — 2(94). — P. 73-81.

9 Hevko I.B. Investigation of the stability of the torsorial vibrations of a screw conveyer under the influence of pulse forces / I.B. Hevko, A.Ye. Dyachun, V.Z. Hud, L.R. Rohatynska, V.M. Klendiy // INMATEH - Agricultural Engineering. Polytechnic University of Bucharest. — 2015. - Vol. 45, № 1. - P. 77-86.

10 Fernandez J.W. Effect of screw design on hopper draw dawn by a horizontal screw feeder / J.W. Fernandez, P.W. Cleary, W. McBride // Seventh International Conference on CFD in the Minerals and Process Industries CSIRO: Melbourne: Australia 9-11 December: 1-6. - 2011.

11 Roberts Alan W. The influence of granular vortex motion on the volumetric performance of enclosed screw conveyors / Alan W. Roberts // Power technology. - 1999. - 104(1). - P. 56-67.

12 Sun X.X. Design method of a vertical screw conveyor based on Taylor-Couette-Poiseuille stable helical vortex / X.X. Sun, W.J. Meng, Y. Yuan // Advances in mechanical engineering. — 2017. — 9(7).

13 Schlesinger D. Screw conveyor calculation based on actual material properties / D. Schlesinger, A. Papkov // Powder Handling and Processing. - 1997. — 9(4).

14 Zareiforoush $\mathrm{H}$. Effect of crop-screw parameters on rough rice grain damage in handling with a horizontal screw conveyor / H. Zareiforoush, M.H. Komarizadeh, M.R. Alizadeh // Journal of Food, Agriculture and Environment. - 2010. - 8(3-4). - P. 494-499.

15 Owen P.J. Prediction of screw conveyor performance using the Discrete Element Method (DEM) / P.J. Owen, P.W. Cleary // Powder Technology. - 2009. - 193(3). - P. 274-288.

16 Рогатинский Р.М. Научно-прикладные основы создания винтовых транспортно-технологических механизмов: моногр. / Р.М. Рогатинский, И.Б. Гевко, А.Е. Дячун. - Тернополь: ФОП «Паляница», 2014. — 280 с.

17 O. Lyashuk. Longitudinal-angular oscillation of wheeled vehicles with non-linear power characteristics of absorber system / O. Lyashuk, T. Pyndus, O. Marunych, M. Sokil // Вестн. Тернопол. нац. техн. ун-та. — 2016. — № 2 (83). — P. $82-89$.

18 Сокол Б.И. Вынужденные колебания гибких трубчатых тел, вдоль которых движется сплошной поток среды / Б.И. Сокол, М.Б. Сокол // Вестн. Нац. ун-та «Львовская политехника» // Динамика, прочность и проектирование машин и приладив. - 2017. - № 866. - С. 60-65.

19 Рогатинский Р.М. Перспективные винтовые конвейеры: конструкции, расчет, исследования: моногр. / Р.М. Рогатинский, И.Б. Гевко, А.Л. Ляшук, В.З. Гудь, А.Е. Дячун, А.Л. Мельничук, Л.М. Слободян. — Тернополь: ФОП «Паляница», 2019. - $212 \mathrm{c.}$

20 Hevko B. Dynamics of auger working body of a multifunctional conveyor / B. Hevko, O. Lyashuk, M. Sokil, O. Skyba, O. Marunych, D. Shmatko // Bulletin of the Karaganda University. Series Mathematics. — 2018. — 1(89). — P. $105-113$. 
21 Lyashuk, O. Torsional oscillations of an auger multifunctional conveyor's screw working body with consideration of the dynamics of a processed medium continuous flow / O. Lyashuk, M. Sokil, Y. Vovk, A. Gupka, O. Marunych // Ukrainian Food Journal. - 2018. - 7(3). - P. 499-510.

22 Патент № 129581. Украина, МПК (2006.01) B65G 33/00, (2006.01) B65G 15/26, E02F 9/00, B65G 33/00. Телескопический винтовой конвейер / Гевко И.Б., Гудь В.З., Шуст И.М. заявители и патентообладатели. — № u201802391; Заявл. 12.03.2018. Опубл. 12.11.2018. - Бюл. № 21.

В. Гудь, И. Гевко, О. Ляшук, О. Гевко, М. Сокол, И. Шуст

\title{
Айналмалы тербелістермен негізделген «телескопиялық бұрама-сусымалы орта» жүйесінің резонанстық тербелістерін зерттеу
}

\begin{abstract}
Мақалада бұрандалы тасымалдағыштарды жасау кезінде телескопия қағидатын пайдаланудың өзектілігі негізделген, олар бүгінде айтарлықтай ұзындығын алу үшін күрделі орындалады, бұл олардың конструкцияларын қымбат және құрылымдық тұрғыдан күрделі етеді. Деректерді қажетті тіркеумен басқарудың автоматтандырылған режимінде жоғары дәлдікпен кең ауқымда технологиялық процесті зерттеу нәтижелерін өлшеуді қамтамасыз ететін эксперименттік жабдық келтірілген. Құрылған математикалық модельдің негізінде «телескопиялық винт-сусымалы орта» жүйесінің физика механикалық және геометриялық параметрлерінен ауытқу бұрыштық жылдамдығының тәуелділігі алынды. Оның негізінде резонанстық жағдай үшін оның тербелістерінің анықтайтын параметрлерінің өзгеру заңдарын сипаттайтын аналитикалық қатынастар алынған. Резонанстық тербелістер кезінде, айналудың едәуір бұрыштық жылдамдығы болған кезде, иілгіш тербелістердің меншікті жиілігі аз және бір мезгілде резонанс арқылы өту амплитудасы аз екені анықталған. Ішкі резонанс арқылы өту кезінде уақыт бойынша айналудың бұрыштық жылдамдығының әртүрлі мәндері үшін жүйенің көлденең тербелісінің амплитудасының нәтижелері берілген, ол едәуір дәрежеде орта қозғалысының физика-механикалық және геометриялық сипаттамаларына байланысты.
\end{abstract}

Кілm сөздер: конвейерлер, механикалық жүйелер, көлік-бөлу жүйесі, динамикалық модельдеу, амплитудалар, резонанс, телескопиялық бұранда, сусымалы орта, бұрыштық айналу жылдамдығы, айналмалы тербелістер.

\section{В. Гудь, И. Гевко, О. Ляшук, О. Гевко, М. Сокол, И. Шуст \\ Исследование резонансных колебаний системы «телескопический винт - сыпучая среда», обусловленных крутильными колебаниями}

В статье обоснована актуальность использования принципа телескопии при создании винтовых транспортеров, которые сегодня для получения значительной длины выполняются сложенными, что делает их конструкции дорогими и конструктивно неоправданно сложными. Приведено экспериментальное оборудование, которое обеспечивает измерение результатов исследования технологического процесса в широком диапазоне с высокой точностью в автоматизированном режиме управления с необходимой фиксацией данных. На основе построенной математической модели получены зависимости угловой скорости возмущения от физико-механических и геометрических параметров системы «телескопический винт - сыпучая среда». На ее базе получены аналитические соотношения, описывающие законы изменения определяющих параметров его колебаний для резонансного случая. Установлено, что при резонансных колебаниях, когда есть значительные угловые скорости вращения, собственная частота изгибных колебаний и одновременно амплитуда перехода через резонанс меньше. Представлены результаты амплитуды поперечных колебаний системы для различных значений угловой скорости вращения во времени при переходе через внутренний резонанс, который в значительной степени зависит от физико-механических и геометрических характеристик движения среды.

Ключевые слова: конвейеры, механические системы, транспортно-разделительная система, динамическое моделирование, амплитуда, резонанс, телескопический винт, сыпучая среда, угловая скорость вращения, крутильные колебания. 


\section{References}

1 Hevko, R.B., Zalutskyi, S.Z., Hladyo, Y.B., Tkachenko, I.G., Lyashuk, O.L., Pavlova, O.M., Pohrishchuk, B.V., Trokhaniak, O.M. \& Dobizha, N.V. (2019). Determination of interaction parameters and grain material flow motion on screw conveyor elastic section surface. INMATEH - Agricultural Engineering, 57 (1), 123-134.

2 Haydl, H.M. (1986). Design aspects of large-diameter tubular conveyor galleries. Proceedings of the institution of civil engineers. Part 1 - Design and construction, 80, 633-639.

3 Owen Philip, J., Cleary Paul, W. (2010). Screw conveyor performance: comparison of discrete element modelling with laboratory experiments. Progress in computational fluid dynamics, 10 (5-6), 327-333.

4 Roberts Alan, W., Bulk Solids (2015). Optimizing Screw Conveyors. Chemical engineering, 122(2), 62-67.

5 Lyashuk, O.L., Sokil M.B., Klendiy V.M., Skyba O.P. \& Slobodian L.M. (2018). Mathematical model of bending vibrations of a horizontal feeder-mixer along the flow of grain mixture. INMATEH - Agricultural Engineering, 55(2), 33-42.

6 Lutsiv, I.V, Hevko, I.B., Lyashuk, O.L. \& Dubynyak, T.S. (2017). Investigation of dynamical impact loads in screw conveyer drives with safety clutches. INMATEH - Agricultural Engineering, 51(1), 69-77.

7 Hevko, R.B., Strishenets, O.M., Lyashuk, O.L., Tkachenko, I.G., Klendii, O.M. \& Dzyura, V.O. (2018). Development of a pneumatic screw conveyor design and substantiation of its parameters. INMATEH - Agricultural engineering, 54(1), $153-160$.

8 Hevko, I., Lyashuk, O., Sokil, M., Slobodian, L., Hud, V. \& Vovk, Yu. (2019). Resonant oscillation of vertical working part of conveyer-loader. Bulletin of the Karaganda University. Series PHYSICS, 2(94), 73-81.

9 Hevko, I.B., Dyachun, A.Ye., Hud, V.Z., Rohatynska, L.R. \& Klendiy, V.M. (2015). Investigation of the stability of the torsorial vibrations of a screw conveyer under the influence of pulse forces. INMATEH - Agricultural Engineering. Polytechnic University of Bucharest, Vol. 45, № 1, 77-86.

10 Fernandez, J.W., Cleary, P.W. \& McBride, W. (2011). Effect of screw design on hopper draw dawn by a horizontal screw feeder. Seventh International Conference on CFD in the Minerals and Process Industries CSIRO, Melbourne, Australia 9-11 December: $1-6$.

11 Roberts Alan, W. (1999). The influence of granular vortex motion on the volumetric performance of enclosed screw conveyors. Power technology, 104(1), 56-67.

12 Sun, X.X., Meng, W.J. \& Yuan, Y. (2017). Design method of a vertical screw conveyor based on Taylor-Couette-Poiseuille stable helical vortex. Advances in mechanical engineering. 9(7).

13 Schlesinger, D., \& Papkov, A. (1997). Screw conveyor calculation based on actual material properties. Powder Handling and Processing. 9(4).

14 Zareiforoush, H., Komarizadeh, M.H. \& Alizadeh, M.R. (2010). Effect of crop-screw parameters on rough rice grain damage in handling with a horizontal screw conveyor. Journal of Food, Agriculture and Environment, 8(3-4), 494-499.

15 Owen, P.J., \& Cleary, P.W. (2009). Prediction of screw conveyor performance using the Discrete Element Method (DEM). Powder Technology, 193(3), 274-288.

16 Rogatinskyi, R.M., Gevko, I.B., \& Diachun, A.E. (2014). Nauchno-prikladnye osnovy sozdaniia vintovykh transportnotekhnolohicheskikh mekhanizmov [Scientific and applied bases of creation of screw transport-technological mechanisms]. Ternopil [in Ukrainian].

17 Lyashuk, O., Pyndus, T., Marunych, O. \& Sokil, M. (2016). Longitudinal-angular oscillation of wheeled vehicles with nonlinear power characteristics of absorber system. Vestnik Ternopolskoho natsionalnoho tekhnicheskoho universiteta - Bulletin of the Ternopil National Technical University, 2 (83), 82-89 [in Ukrainian].

18 Sokil, B.I., \& Sokil, M.B. (2017). Vynuzhdennye kolebaniia hibkikh trubchatykh tel, vdol kotorykh dvizhetsia sploshnoi potok sredy [Inhibited oscillations of flexible tubular bodies along which a continuous flow of medium moves]. Vestnik Natsionalnoho universiteta «Lvovskaia politekhnika». Dinamika, prochnost i proektirovanie mashin i priladiv - Bulletin of the national university «Lviv Polytechnic» Dynamics, strength and design of machines and devices, 866, 60-65 [in Ukrainian].

19 Rogatynskyi, R.M., Hevko, I.B., Liashuk, A.L., Hud, V.Z., Diachun, A.E., Melnychuk, A.L. \& Slobodyan, L.M. (2019). Perspektivnye vintovye konveiery: konstruktsii, raschet, issledovaniia [Prospective screw conveyors: structures, calculation, research]. Ternopil: FOP «Palyanitsa» [in Ukrainian].

20 Hevko, B. Lyashuk, O., Sokil, M., Skyba, O., Marunych, O., \& Shmatko, D. (2018). Dynamics of auger working body of a multifunctional conveyor. Bulletin of the Karaganda University: Series Mathematics, 1(89), 105-113.

21 Lyashuk, O., Sokil, M., Vovk, Y., Gupka, A. \& Marunych, O. (2018). Torsional oscillations of an auger multifunctional conveyor's screw working body with consideration of the dynamics of a processed medium continuous flow. Ukrainian Food Journal, 7(3), 499-510.

22 Hevko, I.B., Gud, V.Z., \& Shust, I.M. (2018). Teleskopicheskii vintovoi konveier [Telescopic screw conveyor]. Patent № 129581, Ukraine. Bulletin No. 21 [in Ukrainian]. 